\title{
The Application of Designated Manager System on Protection Forest Management at Saga Prefecture, Japan - From the Public-Private Partnership and Policy Implementation Approaches
}

\author{
Ching Li, Chiachi Cheng, and Yi-Chine Chu
}

\begin{abstract}
In 2003, Japanese government pointed out the Deigned Manager System to emphasize the importance of combining national and private ability to raise the public benefits and increase citizen participation rates. In addition, Forest Agency hopes to make use private ability to realize the diversified management of forest business, those are the backgrounds of public-private partnerships of forest management in Japan. The purpose of this study was to discuss the application of the Designated Manager System on protection forest management at Saga Prefecture, Japan. The study took Nijinomatsubara Pine Forest and Saga 21 Century Kenminnomori Forest Learning Center as the examples, attempted to define the roles of each organization, the public values, and the co-governors on the policy implication processes. This study applied document analysis and interview with government officers and NPO managers. This study found, the governments played different roles to integrate process for different public value, in Nijinomatsubara, local government plays the role as a communication person between government and locals; in the case of Kenminnomori Forest Learning Center, local government plays the role as a provider, provides the wellness place to NPO and citizens for learning forest related knowledge. Also, vary with issue initiation, each NPO niche abilities for co-governers, Nijinomatsubara's NPO have basically ecological environment knowledge and activity integration ability, the NPO of Saga Forest Learning Center have professional forest related knowledge and woodworking ability. Both of these 2 cases aim to widen range of public participation. Therefore, PPP not only the idea for taking advantage of private organization or the NPO only want to get benefits from governments, but share the value within government, NPO and citizens, and widen the range of public participation.
\end{abstract}

Manuscript received October 10, 2019; revised January 5, 2020. This work was supported in part by the Taiwan Forestry Bureau Protection Forest Management Strategy Study, Grant Number 1080107.

C. Li is with Graduate Institute of Sport, Leisure and Hospitality Management, National Taiwan Normal University, Taipei, Taiwan (e-mail: T94002@ntnu.edu.tw).

C. C. Cheng is with the Industrial Technology Research Institute, Hsinchu, Taiwan (e-mail: chen50no1@gmail.com).

Y. C. Chu is with Forest Administration Division, Forestry Bureau, Council of Agriculture Executive Yuan, Taipei, Taiwan (e-mail: Joyce2008i@gmail.com).
Index Terms-Public private partnership, designed manager system, protection forest, public values.

\section{INTRODUCTION}

In Japan, public-private partnerships (PPP) indicated the cooperation among governmental and private sectors[1], were classified into 11 categories by government dominance and types of constructions. In 2003, the Japan Prime Minister, Junichiro Koizumi, pointed out that in these 11 categories, the Designated Manager System (DMS) was an effective method to embrace the private efforts into wellness facilities. Koizumi believed that wellness facilities were managed by the private not only decreased the expense on public service, but also increased public participation. The Designated Manager System (DMS) implanted into public facilities in 2006, which enabled private managers to manage public facilities in Japan [2].

However, since the 1990s, the issues on public-private partnerships discussed that public participation should strengthen the role of the public participation in the policy development processes, not just on execution [3]-[5]. Therefore, "co-governors" and "sharing public interests and values" have become the major factors to evaluate the public participation [6].

The role of the government was the issue in the Designated Manager System (DMS). The government in DMS provided facilities to select the private sector as an operator based on the operation plan, although the operation plan should be without violating the public interests. For the public service in the facilities, the operators need to negotiate with the government authority to determine the deadline for the business report, the relevant operational items, and the ownership. Therefore, the public participation was an alternative to deliver the public service.

In DMS, using financial incentives to promote public interest is criticized. The long-lasting economic recession and limited budgets for public services were reasons to start the PPP. On the other hand, many public services applied DMS were not beneficial for the majority, but were necessary for the society. In order to pay back financial investments in these public facilities, the public services with self-compensatory or under highly financial concerns were promoted. DMS had forced the managers to be more cost conscious [7]. There had been many controversial discussions on the transformation from equality and social beneficial public goods and services to commercialized 
products in DMS [8].

Therefore, the purpose of this study was to discuss the application of the Designated Manager System on protection forest management at Saga Prefecture, Japan. The study attempted to define the roles, the public values, and the co-governors on the policy implication processes.

\section{RESEARCH METHODS}

This study applied document analysis, focus group interviews, and participant observation in data collection. The document analysis would describe the processes of PPP on protection forest management at Saga Prefecture, Japan. The focus groups interviews would discuss the current issues in the DMS. The participant observation would understand the implantation of protection forest management by DMS.

\section{A. Document Analysis}

The study applied document analysis to define the roles, public values and the partnerships in DMS. The data collection included relevant literature, management records, online information, government publications, books, related projects, journal articles, newspapers and magazines.

\section{B. Focus Group Interviews}

The study interviewed 5 focus groups to discuss the role, the public value, and the partnerships. The 5 focus groups are the city, the country, and the Forest Service and two operators.

\section{Participant Observation}

The researchers would participant three public participation event on protection forest management at Saga Prefecture, Japan. These events would be operated in the DMS.

\section{NATIONAL Forest StRUCTURE AND MANAGEMENT IN SAGA}

In Japan, the highest level of National Forest Structure is Forest agency, and has 7 Regional Forest Office in each area (Hokkaido, Tohoku, Kando, Chubu, Kinki, Shikoku and Kyusyu) , 98 district forest offices and 1256 local forest offices. Besides, forest offices also cooperate with agriculture, forest and fisheries department of local government and local NPO.

Japan's Protection forest are divided into national forests and private forests. Therefore, the public forests are the part of the National Forest Management. The role of local government is to support the management of national forests and manage the private forests with owners together. The local operators of forest are directly managed or appointed by the government basic on the rules of DMS.

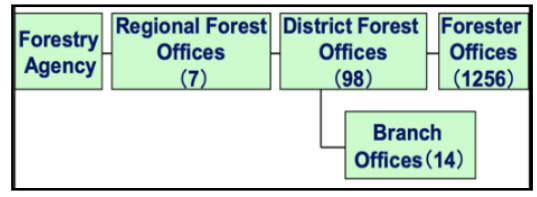

Fig. 1. Organizational Structure for National Forest Management [9].

This study will analyze 2 case, Nijinomatsubara old pine forest and Saga 21 Century Kenminnomori Forest learning center. The first case is belonged to Saga District Forest Office, and the second case is belonged to Agriculture, forest and fisheries department of Saga Prefecture.

\section{A. Saga District Forest Offices}

Saga District Forest Offices belongs to Kyushu Regional Forest Offices. The main duties are : (1)manage the beneficial forests; (2) promote the idea of protecting beneficial forests, such as avoiding global warming, Homeland security, forest and biodiversity preservation; (3)provide and make use stable forest resource; (4) educate talent for managing private forest together; (5)support national forest area tourism [10]

\section{B. Agriculture, Forest and Fisheries Department of Saga Prefecture}

The main duties of Agriculture, forest and fisheries department of Saga Prefecture are (1) Forest lighting: The implementation of thinning operation on abandoned plantations to increase the luminosity of the forest, blend the conifers with broad-leaved trees, form a mixed forest, and strengthen the disaster prevention function; (2) Forest breeding protect protection forest to maintain and enhance forest function; (3) Next-generation forest regeneration: thinning and reforestation for areas with suitable geographical conditions, reducing the area of abandoned forests; (4) Afforestation with citizens; (5) Protection of Precious forest; (6) Promote Saga forest recovering by using mass media.[11]

\section{The VAlue And Co-governors of PPP OF Forest MANAGEMENT IN SAGA}

Nijinomatsubara pine forest is a national protection forest, belonged to Saga District Forest Office, Saga 21 Century Kenminnomori Forest learning center is including national protection forest and private forest area, these 2 cases have different management system of PPP.

\section{A. The PPP Structure of Nijinomatsubara Pine Forest}

Nijinomatsubara pine forest which is a national protection forest and located in Karatsu city, Saga prefecture. In the past, pine branch was an important fuel of daily life, however, nowadays, because of the needs of pine branch has been reduced, idle pine branch caused the problem of Bursaphelenchus xylophilus tragedy, the landscape has been destroyed. In 2006, citizens hoped to recover the landscape of white sand and green pine, and made negotiations with Saga District Forest Office. After that, in 2007, local government, Karatsu city hall corporated citizens, NPOs and government to organize council and started to find the manager of this project. From 2008, based on the PPP, the council got the agreement from Saga District Forest Office, then composed the Nijinomatsubara pine forest restoration and conservation project, and appointed 'NPO Karatsu Environment and Disaster prevention Promotion Institute KANNE to be the manager.[12]

The meaning of KANNE means the network of environment, KAN means kanngyo, which is the meaning of environment in Japanese, NE means network. The main 
purposes of this NPO are to avoiding global warming, promoting environment education and making community network. According to those purposes, they take place lectures and speeches, and to be a platform of disaster prevention information exchange. The NPO has chairman, vice chairman and 2 inspectors, the office has 1 director and 3 staff, the director was major in Eco-environment.

According to the specification of this project, the main duty of KANN is to lead citizens and volunteers to participate in activities of restoration and conservation project and promote the issue of restoration and conservation. The restoration and conservation actives mainly have 2 types [13]:

1. Annually type: participate forest preserves and forest operation activities (Keep Pine Project, KPP)4 times per year.

2. Adopt System: adopt a Counter for tatami mats area, cleaning the adopted area autonomy

As the organizer, KANNE provides sweepers and supporting the activities including registrations process, insurance procedures, and recycle trash after cleaning.According to the contract with council, the duty of KANNE is as following [14]:

1) To be the contract person of Nijinomatsubara old pine forest restoration and conservation project with CSOs, Companies, groups and citizens. (2) Encouraging CSOs, Companies, groups and citizens for participating Nijinomatsubara old pine forest restoration and conservation activities; (3) Managing and operating Nijinomatsubara old pine forest restoration and conservation related activities;(4) Taking place related activities and promoting each events; (5) Organizing related operating procedure of each activities; (6) Supporting recreation forest office; (7) Writing and submitting reports; (8) Supporting council.

The duty of Saga District Forest Office is to protect and maintain this national forest, therefore, the cooperate with Saga prefecture, Karatsu city hall and locals to practice bug buster and lopping service, and also doing annually forest investigations. The main duty of KANNE is communicate with government and locals, and lead volunteers to do cleaning Nijinomatsubara project and hope to recover white sand and green pine in the future. [15]

The budget is about 8 million Yen each year and mainly providing by Saga District Forest Office, beside, NPO also looked support from companies, like Asahi Beer and Itoen Tee, the companies donated part of benefit to council and transfer to the NPO. Based on the DMS, NPO also can create or sell their own products to increase their income. Now, the NPO almost can invite more than 6000 volunteers and 154 groups to participate this project per year, although it is not ready to recover white sand and green pine, but, because of sponsorship and adopted system, this project not only invited locals but also volunteers from different cities or countries.

The attribute of KANNE is environment education and idea promotion, the staff at least have basically knowledge of ecological environment knowledge and strong activity integration ability. The government has responsibility to provide the Bursaphelenchus xylophilus buster and lopping service, and provide Nijinomatsubara to be a platform to promote environment education.

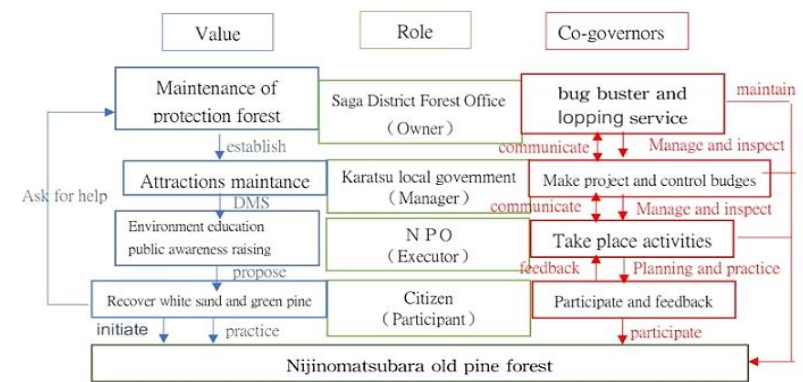

Fig. 2. The roles, the public values, and the co-governors of Nijinomatsubara old pine forest.

\section{B. The PPP of Saga 21 Century Kenminnomori Forest Learning Center}

In order to promote the importance of forest, Forest Agency establishes Forest learning center at each prefecture , also basic on the designated manager system to appoint organizers for each learning center. About the Saga 21 Century Kenmin no Mori Forest learning center, Saga prefecture government said, the manage is NPO Minnanomori(everyone's forest) Project and deal a 5 years contract. NPO Minnanomori(everyone's forest) Project was established in 207, the purposes are promote the importance of forest to teenagers to locals, and hope to reach the goals of forest breeding, recovering forest and protecting environment. The duty of NPO are afforestation, forest and environment education and Community development. The chairman majors in eco-environment and forest research, the 13 staff have professional forest related knowledge and woodworking ability. NPO said the visons of organize forest learning center are, Forest nourishment, Increase in forest area, and make use on forest resource [16]. NPO has responsibility on the duty of bug buster and lopping service, and also takes place craft workshop and woodworking lesson, aims to provide a relaxable place to citizens. In the center, includes natural forest and plantation forest, and provide forest learning exhibition, craft workshop and woodworking lesson classroom, and outdoor space such as camping area, playground and bicycle path.

About 50 60 thousands tourisms are visiting this center, including 10 thousands tourisms comes for the purpose of using indoor facility. The owner of this area is forest agency, the local government owns and manages the facility, and provide 20 million Yen to the NPO per year. The NPO don't need to pay rent to government and can receive payment form tourisms by taking place craft workshop and woodworking lesson classroom or form renting camping place or bicycle.

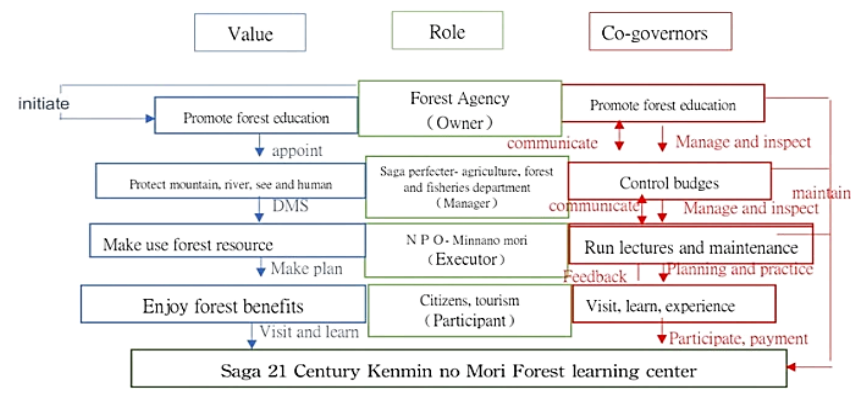

Fig. 3. The roles, the public values, and the co-governors of Saga 21 Century Kenmin no Mori Forest learning center. 
Above all, form forest to NPO and citizens, they are contacting by the value of forest learning, government provides the space, NPO provides professional ability to manage the center, the citizens can enjoy forest benefits at this space.

\section{CONCLUSION}

This study have divided conclusions into three parts.

\section{A. The Different Integration Process for Public Value}

The first case, Nijinomatsubara pine forest, the starting point is the issue of citizens awareness of recovering white sand and green plain, the government started to make project, set up council and appoint the NPO to be the manager.

Saga 21 Century Kenminnomori was stated by the idea of forest education of Forest Agency. Basic on the Forest Agency's policy of forest education, the local forest office and local government started to find the space, make contracts and appoint the organizers.

\section{B. A Wide Range of Public Participation}

In 2003, Japanese government pointed out the importance of combining national and private ability to raise the public benefits and increased citizen participation rates, in addition, Forest Agency hopes to make use private ability to realize the diversified management of forest business, those are the backgrounds of PPP of forest management in Japan.

In this study, both of these 2 cases all aim to improve efficiency, reduce the cost and Raise citizenship and promote the value of forest. The local government support citizens to make Nijinomatsubara pine forest protection project, and appoint NPO to promote related idea to citizens, locals, even the participants from different countries, then arouse more people to concern the issue of recovering white sand green pine. The Forest Agency emphasized the importance of forest education, the local forest office corporates with forest professional NPO and Saga prefecture, attracted at least 50 thousands visitors from several cities for learning, closing, experiencing the benefits of forest.

\section{Niche Abilities for Co-governors}

According to the contract content, KANNE as a manager of Nijinomatsubara pine forest, plays the role of communication person between citizens and government, they receive policy and budges from council and lead citizens to participate in activities and promote the eco-environment education through those events. The staff have basically ecological environment knowledge and full of activity integration ability.

The NPO Minnanomori Project need to maintain the center, includes bug buster and lopping service and hold the woodworking class lectures, therefore, most of members have professional forest related knowledge and woodworking ability.

Above all, although these two cases are using Designated Manager System, however, the different ways of Issue initiations caused the governments paly different roles of these cases. For Nijinomatsubara project, the local government mainly paly a communication role to support and rise the civic awareness and eco-environment idea; for Saga Forest learning center, the government aims to provide wellness facility and service to attract citizens' participation wiliness.

Therefore, this study found PPP not only the idea for taking advantage of private organization or the NPO only want to get benefits from governments. The policy implication processes of PPP is government make the direction, and find appropriate NPO or private organization, to share the same value with government, NPO and citizens, then, to widen the range of public participation.

TABLE I: The PPP of NiJinOMATSUBARA Old PINE Forest AND SAgA 21 CEnTURy KenMin NO MORI Forest LEARNING CENTER

\begin{tabular}{|l|l|l|}
\hline & $\begin{array}{l}\text { Nijinomatsubara old pine } \\
\text { forest }\end{array}$ & $\begin{array}{l}\text { Saga 21 Century Kenmin no Mori } \\
\text { Forest learning center }\end{array}$ \\
\hline Ownership & National Forest, Preserved Forest & $\begin{array}{l}\text { National Forest, Private Forest. Preserved } \\
\text { Forest }\end{array}$ \\
\hline Issue initiation & Consciousness Of Citizenship & Policy of Forestry Agency \\
\hline Function & Issue initiation & Education and facility maintenance \\
\hline NPO & KANNE & Minnanomori Project \\
\hline PPP Type & Designated Manager System & Designated Manager System \\
\hline Contract & 5 years contract & 5 years contract \\
\hline Duty & Promoting the idea & $\begin{array}{l}\text { ecological education - forest preserves } \\
\text { and forest operation }\end{array}$ \\
\hline Member' s ability & $\begin{array}{l}\text { Have basically ecological } \\
\text { environment knowledge and } \\
\text { activity integration ability }\end{array}$ & $\begin{array}{l}\text { Have professional forest related } \\
\text { knowledge and woodworking ability }\end{array}$ \\
\hline $\begin{array}{l}\text { Budges } \\
\text { government }\end{array}$ & 8 million Yen/ per year & 20 million Yen/per year \\
\hline funding source & Fundraising box, sponsors & $\begin{array}{l}\text { woodworking class, selling Crafts, } \\
\text { renting camping area and bicycles }\end{array}$ \\
\hline
\end{tabular}

\section{APPENDIX}

According to the PPP Rules and Local Autonomy La in Japan, the DMS rules is applicable to following facilities:

1. Sports related facilities: pool, gym, stadium, Athletic field, tennis court and so on.

2. Park: park, botanical garden, aquarium and so on.

3. Culture related facilities: library, museum, Art museum, history museum and so on.

4. Medical related facilities: hospital, Center of rehabilitation.

5. Welfare related: elderly care facilities, disabled care facilities, nursery school, child welfare residential facility and so on.

6. Daily life related: drainage system, funeral hall, parking space and so on.

7. Education related facilities: forest school, learning center, and so on.

\section{CONFLICT OF INTEREST}

This study is founded by Taiwan forestry Bureau .

\section{AUTHOR CONTRIBUTIONS}

All authors conducted the research; Chiachi Cheng collected and wrote the part of date related to Japan; Yi-Chine CHU provided the information of government strategy of forest management; Ching LI analyzed the data; all authors had approved the final version.

\section{ACKNOWLEDGMENT}

We would like to express our sincere gratitude to Taiwan forestry Bureau for supporting to this study. Besides, we 
would like to thank you Saga District Forest Offices, Agriculture, forest and fisheries department of Saga Prefecture, KANNE and Minnanomori Project for providing those information.

\section{REFERENCES}

[1] Cabinet Office, Government of Japan. (2000). About PPP. [Online]. Available: http://pfi-as.jp/pfi/pfi/pfi_about.html

[2] M. Taniguchi, "The impact of the limited government policy on the management of the Japanese prefectural museums (No. 2016-026)," Institute for Economics Studies, Keio University, 2016.

[3] C. M. Stivers, "Active citizenship and public administration," in Gary L. Wamsley et al., Eds. Refounding Public Administration, Newbury Park, CA: Sage, 1990, pp. 246-273.

[4] J. Meldon, M. Kenny, and J. Walsh, "Local government, local development and citizen participation: Lessons from Ireland," in W. R. Lovan, M. Murray, and R. Shaffer, Eds. Participatory Governance: Planning, Conflict Mediation and Public Decision-Making in Civil Society, Burlington, VT: Ashgate, 1990, pp. 39-59.

[5] J. Cavaye, "Governance and community engagement: The Australian experience," in W. R. Lovan, M. Murray, and R. Shaffer, Eds. Participatory Governance: Planning, Conflict Mediation and Public Decision- Making in Civil Society, Burlington, VT: Ashgate, 2004, pp. 85-101.

[6] C. M. Stivers, "Refusing to get it right: Citizenship, difference and the refounding project," in G. L. Wamsley and J. F. Wolf, Eds. Refounding Democratic Public Administration: Modern Paradoxes, Postmodern Challenges, Thousand Oaks, CA: Sage, 1997, pp. 260-278.

[7] M. Taniguchi, "The impact of the designated manager system of Japanese public halls: Measuring technical, allocative, and productive efficiency," Keio Economic Studies, vol. 54, pp. 33-47, Japan, 2018.

[8] Y. Hirose, "Use of private sector dynamism in Japanese public library: Ebina city central library," Bibliothek Forschung und Praxis, vol. 41, no. 2, pp. 257-261, Japan, 2017.

[9] Forest Agency of Japan. (2009). Organizational structure for national forest management. [Online]. Available: http://www.maff.go.jp/e/index.html

[10] Saga District Forest Offices. (2009). The functions of forest. [Online]. Available: http://www.rinya.maff.go.jp/kyusyu/saga/sub3.html

[11] Saga Prefecture, Let's protect Saga's Forest Together! The DM of Forest Education, Japan, 2018.

[12] H. Hitoshi, A. Kiyoko, and F. Wakako, The Policy of Nijinomatsubara Nijinomatsubara, Japan, 2018.

[13] F. Wakako, The Director of KENNE, Interweave Information, Interviewed Date, 2019.

[14] Nijinomatsubara Council, Consignment Specification of Nijinomatsubara Nijinomatsubara in 2018, 2018.
[15] F. Wakako, The Director of KENNE, Interweave Information, June 26 , 2019.

[16] T. Yoshimura, The Director of Saga 21 Century Kenmin no Mori, Interweave Information, June 29, 2019.

Copyright $\odot 2020$ by the authors. This is an open access article distributed under the Creative Commons Attribution License which permits unrestricted use, distribution, and reproduction in any medium, provided the original work is properly cited (CC BY 4.0).

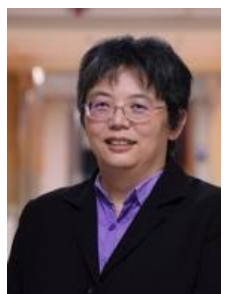

Ching $\mathbf{L i}$ is a professor of Graduate Institute of Sport, Leisure and Hospitality Management, National Taiwan Normal University, Taiwan. She had a PhD degree in environmental science, State University of New York, NY, USA. Her research expertise focuses on recreational resource management, environmental planning and assessment, and leisure behavior.

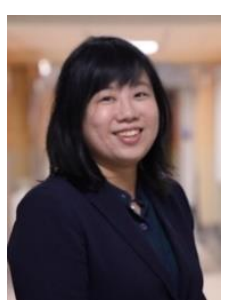

Chiachi Cheng obtained a doctor of sport science degree from Waseda University, Japan in 2014, a master of education degree from National Taiwan Normal University, Taiwan in 2008.

She was a project assistant professor for National Institute of Sport and Fitness, Kagoshima, Japan. She is a postdoctoral research fellow for Industrial Technology Research Institute, Hsinchu, Taiwan.

Dr. Cheng co-authored "well understood Sport Anthropology" (Tokyo, Japan: Minervashobo, 2017) with Prof. Tsuneo SOGAWA. And co-authored "The discussion of multi-purpose management issues in protect forest from forest value orientation approaches" (Taipei, Taiwan: Leisure \& Society Research, 2019) with Prof. Ching Li and Ms. Yi-Chine Chu.

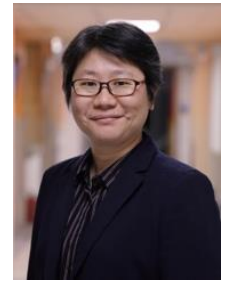

Yi-Chine Chu obtained a master of landscape an design degree from Thuaghai University, Taiwan in 2005.

She is a dean of Forest Administration Division Forestry Bureau, Council of Agriculture Executive Yuan, Taipei, Taiwan.

Ms. Chu co-authored "The discussion of multi-purpose management issues in protect forest from forest value orientation approaches" (Taipei, Taiwan: Leisure \& Society Research, 2019) with Prof. Ching Li and Dr. Chiachi Cheng. 